\title{
Purchasing power parities for Latin America and the Caribbean, 2005-2013: methods and results
}

\author{
Hernán Epstein and Salvador Marconi
}

ABSTRACT

This work sets out some methodological aspects and gross domestic product (GDP) series for Latin America and the Caribbean for the period 2005-2013, expressed in purchasing power parities (PPP), and points out a number of limitations applying to this sort of exercise. Comparisons are made with series (at current and constant prices) denominated in dollars at market exchange rates, and also with the results of the 2005 round of the International Comparison Programme. A number of hypotheses are advanced to interpret the behaviour of the main economic variables calculated in the study. on Drugs and Crime. hereps@gmail.com

Salvador Marconi is a former staff member of the Economic and Environmental Statistics Unit of the Economic Commission for Latin America and the Caribbean (ECLAC). salvadormarconi@hotmail.com 


\section{I}

\section{Introduction}

Series of purchasing power parities (PPP) and of the components of gross domestic product (GDP) - or at more disaggregated levels - are extremely useful for analysing competitiveness, supporting negotiations on trade agreements and making economic policy decisions. They can also be used in international poverty measurements.

In a recent piece of work, entitled Global absolute poverty fell by almost half on Tuesday, Dykstra, Kenny and Sandefur (2014) show the substantial changes in many countries' poverty estimates based on the results of the 2005 round of the International Comparison Programme (ICP) and on extrapolations from the results of the 2011 round. This work shows the importance and the sensitivity of such calculations.

Accordingly, it is important to devote the necessary resources to obtain robust PPP figures through the ICP rounds, at least under a rolling benchmark scheme similar to that used by Eurostat and the Organization for Economic Cooperation and Development (OECD). Meanwhile, in the region we may use estimates which, notwithstanding the methodological limitations set forth in the following pages, are reported in this work.

The literature on the technical aspects of PPP is extremely broad. There is also a long list of publications on methods of calculation and the particular results obtained in ICP rounds, both from academia (such as the Penn World Tables) and from international agencies (World Bank, OECD, among others). By contrast, few works generate and analyse regional statistical series prepared on the basis of methodologies that complement those used to calculate PPP in the years of major statistical operations (rounds) when prices are surveyed and weights calculated.

The main objective of this work is to present some methodological aspects and GDP series for Latin America and the Caribbean for the period 2005-2013, expressed in PPP, as well as some of the limitations of this exercise. Comparisons are made with the results of the 2005 round of ICP and with dollar-denominated series (at current and constant prices) at market exchange rates. A number of hypotheses are advanced to interpret the behaviour of the

$\square$ The authors, who are former staff members of the Economic and Environmental Statitistics Unit of the Economic Commission for Latin America and the Caribbean (ECLAC), are grateful for comments and suggestions made on a previous version of this work by an anonymous referee. main economic variables calculated in the framework of the investigation.

Unlike an earlier work by the same authors, in which PPP series (2000-2011) were calculated on the basis of the 2005 round of ICP, the series presented in this study are based on the 2011 ICP results published by the ICP Global Office, as well as in more recent national accounts data published by the countries of Latin America and the Caribbean for the period 2005-2013 (Epstein and Marconi, 2014).

Simply put, PPP between two countries (A and B) is the ratio between the number of country A's monetary units required to buy - in country A - a product of equal quality and in equal quantity as could be bought by one of country B's monetary units in country B. Here, B is the reference country.

Using econometric calculations, these PPPs - initially calculated for staple products - can be calculated for groups of products (known as basic headings), and even at the level of GDP and its components.

On the basis of PPP, price differences can be analysed between countries and spatial comparisons made (geographical dimension), selecting a given country as a reference (usually the United States).

PPPS are used to measure not only the "real" size of a country's or a region's economy, but also to obtain more robust indicators of level of economic development (such as per capita GDP expressed in PPP), and of productivity and competitiveness, as well as better measurements of poverty.

Several Latin American countries (Ecuador, El Salvador and Panama) have adopted dollarization as an exchange-rate regime, which means forgoing some degrees of monetary policy freedom. Together with the calculation of real exchange rates, the updated PPP series afford these countries' economic authorities useful indicators of competitiveness.

Currently, PPPs are calculated in the framework of an exercise coordinated by the World Bank and implemented globally through the ICP. OECD and Eurostat run a regular programme to perform these calculations for their member countries.

Ideally, this programme should be carried out every year in every country in the world, which would provide annual PPP series. Unfortunately, owing to financial and logistical restrictions, PPPs are only available for the 
years of the ICP rounds, ${ }^{1}$ although they can be estimated for the years in which these great statistical sweeps are not conducted at the global level.

Academics from the University of Pennsylvania, led by Alan Heston, calculate series of PPP and of macroeconomic aggregates expressed in PPP for all the countries (Heston, several years). Starting in 1996, they use the results of previous ICP rounds as a benchmark to estimate long series, published under the name of Penn World Tables (PWT). Similarly to the work carried out here, PWT use the information from the ICP rounds as a reference to obtain PPP series.

However, in many cases, since these are efforts at the global level, the information put into the PWT (and into the World Bank database) is not the most up-todate information for Latin America and the Caribbean. Moreover, the PPP extrapolations presented in the PWT use multiple reference years obtained from different ICP rounds, whereas this work focuses on the latest year available, on the premise that this provides the best quality of information and more advanced calculation methodologies than previous rounds.

1 The last two rounds of ICP take 2005 and 2011 as reference years.
In effect, the estimates presented in this study are conducted on the basis of the latest ICP information available, extrapolating (and retropolating) parities using the deflators derived from the national accounts of the Latin American and Caribbean countries and the United States, a method which has the advantage of being simple and inexpensive.

GDP series are presented at constant and current prices expressed in PPP for 2005-2013, a short period which, nevertheless, is statistically influenced by the crisis of 2008-2009, which could have repercussions on the results in both price and volume terms. Effectively, the financial crisis unleashed in those years, the end of the commodity price boom and the considerable fall in the investment rate over the latter years of the period analysed had a strong impact on relative prices of the goods and services that make up the output of the countries of Latin America and the Caribbean, on their PPP and, obviously, on the low rates of total and per capita GDP growth recorded in most of the countries of the region.

Following this introduction, this article is structured as follows: section II offers an overview of the methodology used in this work. Next, section III carried out comparisons of the results obtained in the study. Section IV offers final remarks. Lastly, a statistical annex is provided.

\section{II}

\section{Brief methodological overview}

The System of National Accounts (sNA, 2008, paragraphs 15.232 and 15.233) refers to the methods of updating PPPs:

"The method commonly used to extrapolate PPPs from their benchmark year to another year is to use the ratio of the national accounts deflators from each country compared with a numeraire country [...] to move each country's PPPs forward from the benchmark.

[...]

Theoretically, the best means of extrapolating PPPs from a benchmark year would be to use time series of prices at the individual product level [...] In practice, it is not possible [...]. Therefore, an approach based on extrapolating at a macro level (for GDP or for a handful of components of GDP) is generally adopted" (EU/IMF/OECD/United Nations/ World Bank, 2009).
SNA 2008 recommends using a benchmark year in which PPPs are robust (that is, a year in which an ICP round has been held), then to extrapolate (or retropolate, or both) using national accounts deflators.

However, a methodological problem arises in relation to the level of disaggregation. Extrapolating at the individual product level, as suggested in paragraph 15.233 of SNA 2008, would imply conducting a global comparison programme that would yield the required information (with the limitations typical of a project of this nature).

Obviously, if the information is available, ideally extrapolations should be performed at as detailed a level as possible, for example, for the major components of GDP spending or even at the level of certain basic headings. The choice of level at which to extrapolate depends chiefly on the quantity and quality of information available, 
as regards both the national accounts and the prices of goods and services in a standard basket of products. ${ }^{2}$

As noted, the results of the 2011 round published by the World Bank were used to build series for 2005-2013, as well as the information in CEPALSTAT (available up to January 2015) to retropolate (2005-2010) and extrapolate (2012-2013) PPP values. The retro/ extrapolation of PPPs for 2011 was performed according to the recommendations of SNA 2008, depending on the availability of implicit deflators and PPPs at the GDP level, using the following formula:

${ }^{2}$ A summarized presentation of the aggregation methods used in the framework of ICP is given in Epstein and Marconi (2014).

$$
P P P_{t+k}^{A}=P P P_{t}^{A} \times \frac{I D_{t+k}^{A}}{I D_{t+k}^{R}}
$$

where $P P P_{t}^{A}$ is the PPP for country A, in period $t ; I D_{t+k}^{A}$ is the implicit GDP deflator of country A in period $t+k$ (base $=100$ for period $t$ ); and $I D_{t+k}^{R}$ is the implicit GDP deflator of benchmark country $\mathrm{R}$ in period $t+k$ (base $=100$ for period $t)$. The main results are reported in the annex.

It should be noted, however, that the calculation of national accounts deflators use structures that vary over time in the denominators, which may obviously hinder comparison. Ideally, these deflators should be obtained on the basis of a fixed basket in the benchmark year.

Box 1

THE ECONOMIC THEORY BEHIND PPP

The concept of purchasing power parity arose in the sixteenth century in the form of the law of one price, which established that the prices of two identical goods in two different countries should be equal over the long term, owing to international arbitrage. Thus, if the price of a good were to rise more in one country than in the other, the exchange rate between the two countries' currencies should vary proportionally to maintain international parity.

Expanding this notion to a group of goods, the PPP index for the whole economy should be equal to the long-term exchange rate.

However, there are reasons why the law of one price - and thus parity between PPPs and exchange rates - are not fulfilled, such as transport costs, taxes or trade tariffs, or the non-tradability of certain services between countries.

There is also another type of theory which can explain the differences in price levels between countries. The Balassa-Samuelson hypothesis establishes that countries with higher productivity (and therefore higher income) will have higher prices. A consequence of this hypothesis is the Penn effect, whereby countries with a higher GDP will have systematically higher price levels (calculated as the ratio between PPP and the exchange rate) and vice versa. This would also indicate that, as a country develops and its relative wealth increases, so will its relative prices.

Source: Prepared by the authors.

Once the PPP series had been calculated for the period, GDP series were obtained by dividing the values at current prices in national currency $(\mathrm{NC})$ by the corresponding PPP estimated for each year between 2005 and 2013. This yielded the series expressed in PPP at current prices in United States dollars, for 30 Latin American and Caribbean countries. ${ }^{3}$

\footnotetext{
3 Argentina, Cuba and Guyana are not covered in this work. Cuba was not included in the study because the ICP Global Office included the following note in the results of the 2011 round of ICP: "The official GDP of Cuba for reference year 2011 is 68,990.15 million in national currency. However, this number and its breakdown into main aggregates are not shown in the tables because of methodological comparability issues. Therefore, Cuba's results are provided only for the PPP and price level index" (World Bank [online] http://icp.worldbank.org).
}

Meanwhile, the price level index (PLI) is defined as follows:

$$
P L I_{t}^{k}=\frac{P P P_{t}^{k}}{X R_{t}^{k}}
$$

where $P L I_{t}^{k}$ is the price level index for country $k$ in year $t$; and $X R_{t}^{k}$ is the market exchange rate of country $k$ at time $t$ with respect to the benchmark country, in this case the United States.

Argentina and Guyana were not included because they opted out of the 2011 round. 
The price level index is a percentage that indicates the level of prices in country $k$ with respect to the level of prices in the United States, taking the dollar as the benchmark currency. Thus, a PLI value equal to 0.8 (or $80 \%$ ) means that in country $k, 80$ cents will buy the same as a dollar buys in the United States. Alternatively, it may be stated that price levels in country $k$ are $20 \%$ lower than in the United States.

Lastly, the GDP series at constant prices expressed in PPP was calculated taking 2010 as the reference year. These series were obtained by taking 2010 GDP values at current prices and extra/retropolating for the period 2005-2013 using the corresponding growth rates of each country's GDP series, at constant prices. ${ }^{4}$

In this exercise, the series are expressed in 2010 prices (of the United States), which is also the base year of the regional series published by ECLAC.

Dalgaard and Sorensen (2002) warn that the aggregate method may bias the estimates if the structures of the countries' economies vary over time. The only way to mitigate this effect is to perform the extrapolation at the most disaggregated level possible.

In order to evaluate the results and compare the two methodological approaches (GDP at the highest level of aggregation compared with disaggregation), PPPs were calculated by components. The level of the components should match the PPPs published by ICP in the 2011 round: individual consumption expenditure

4 This is equivalent to using the series in constant prices in national currency for the period 2005-2013 and dividing the values by the PPP of the reference year chosen. by government, collective consumption expenditure by government, consumption expenditure by households, gross capital formation, and exports and imports of goods and services. For each of these, the corresponding implicit GDP deflators were used to extra/retropolate PPPs for the reference year. On the basis of these series of PPPs by component, the EKS method was used to obtain the GDPlevel PPPs for each of the years in the reference period.

The information was obtained from the ECLAC database (CEPALSTAT) $)^{5}$ and, in the case of the benchmark country (United States), from the website of the Bureau of Economic Analysis (www.bea.gov). ${ }^{6}$ For imports and exports of goods and services, the exchange rates of each year were used as PPPs, as recommended by ICP.

In order to eliminate the biases mentioned by Dalgaard and Sorensen (2002), it would be necessary to extrapolate at the product (not the component) level. The results obtained in this study therefore still include these biases, although to a lesser extent than the results of extrapolation at the aggregate GDP level.

\footnotetext{
5 In the case of central government consumption expenditure, it is necessary to work with the breakdown into collective and individual consumption, and calculate the respective deflators separately, because this is the level of disaggregation published by ICP 2011. However, owing to the lack of information in this respect for most of the countries, it was decided to use the deflator for total general government consumption in the calculation of these two components. 6 Data on general government consumption broken down into individual and collective components are not available for the United States, so estimates were obtained on the basis of the information published in the ICP rounds, as well as auxiliary data published by the countries.
}

\section{III}

\section{Main results}

A number of comparisons can be made with the results obtained in this study. Below are presented the main differences in ranking of the countries of the region when per capita GDP is expressed in market exchange rates and in PPP for the reference years (2005 and 2011). Series of total and per capita GDP expressed in PPP and at market exchange rates are also compared, at both current and constant prices, as well as price levels, thus showing which countries are more "expensive" and which "cheaper" in the region. We also report certain elements that arise from the comparison between the results obtained using the components method and, lastly, we analyse a number of factors that should be taken into consideration when performing this sort of comparison.

\section{Statics comparison: ranking of countries in 2005 and 2011}

Figure 1 shows the differences in the ranking when market exchange rates (XR) and when PPP deflators are used for 2005 and 2011. The PPPs used in the calculation are those published in the ICP framework 
for the corresponding rounds: for this reason, only the results for the ten countries participating in both rounds are included: Bolivarian Republic of Venezuela, Brazil, Chile, Colombia, Ecuador, Mexico, Paraguay, Peru, Plurinational State of Bolivia, and Uruguay).

By exchange rate (XR), Mexico is the country with the highest per capita GDP in 2005, followed by Chile. This order is reversed if PPPs are used. This is because the price level is lower in Chile than in Mexico.

Similarly, there are significant differences in the ranking with respect to 2011: Brazil is the country showing the biggest relative difference, moving from third place (using XR) to fifth place using the PPP deflator. In 2011 the Brazilian currency, the real, underwent a sharp appreciation, reaching an average rate of 1.67 to the dollar, the lowest exchange rate in the period 2000-2013. This had a direct impact on Brazil's nominal per capita GDP in dollars that year, which is neutralized when PPPs are used as the deflator.

Four hypotheses could be put forward to interpret the differences in price level among the countries of the region, and each must be duly studied and verified. The first relates to differences in countries' degrees of trade and tariff openness; the second to levels of market concentration and differentiation of the products making up the "GDP basket." A third, not insignificant, element in price determination and evolution is the effect of monetary and fiscal policies, as well as the way in which economic agents form (anticipate) their expectations. Last but not least, productivity gaps, i.e. different dynamics

FIGURE 1

Per capita GDP in dollars at current prices, deflated with market exchange rates (XR) and PPPS, 2005 and 2011

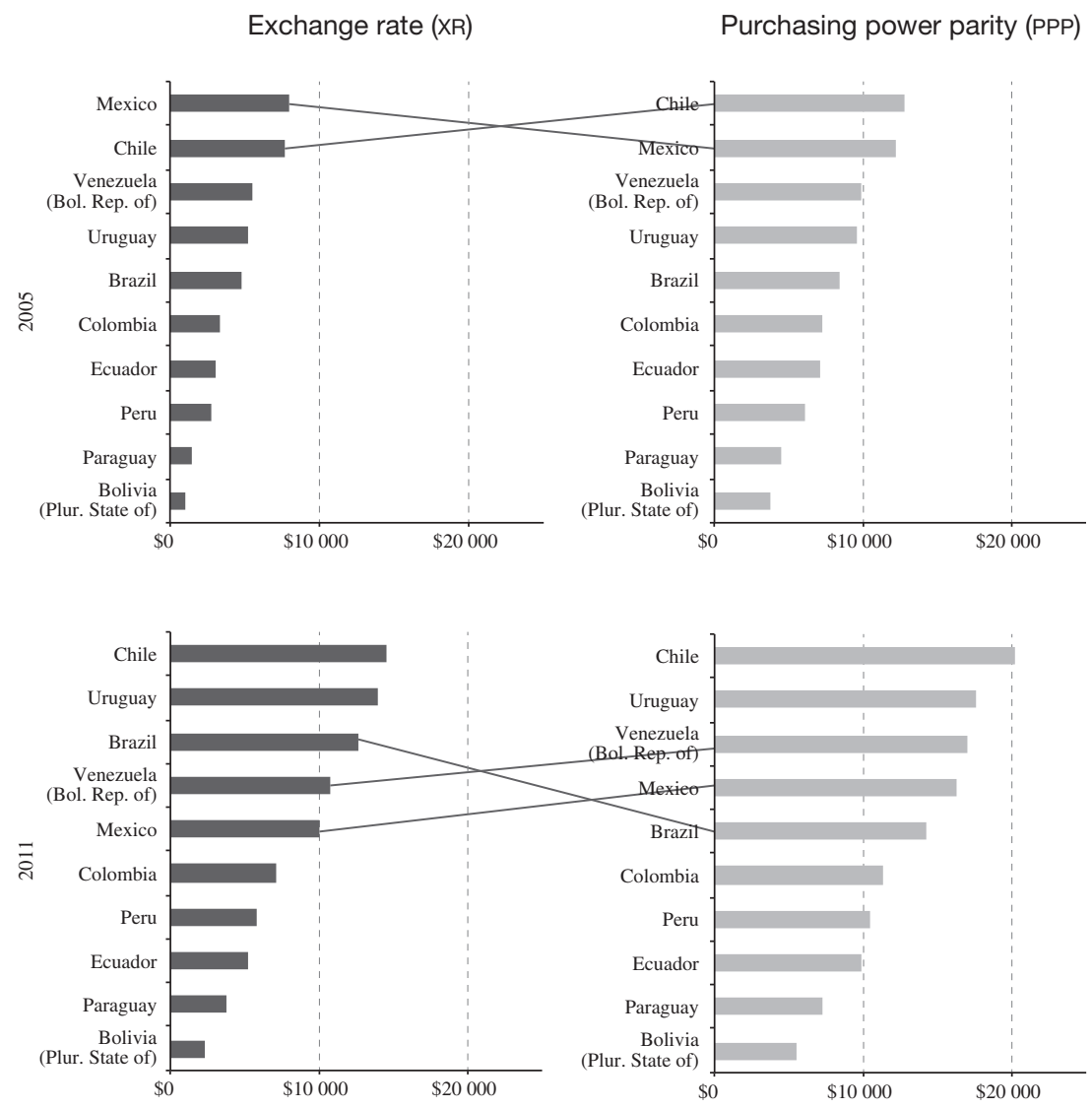

Source: Prepared by the authors, on the basis of Economic Commission for Latin America and the Caribbean (ECLAC), Databases and Statistical Publications (CEPALSTAT) [online] http://estadisticas.cepal.org/cepalstat/WEB_CEPALSTAT/Portada.asp?idioma=i; and World Bank Data Base [online] http://data.worldbank.org/.

Note: GDP: Gross domestic product. 
in processes of surplus generation and appropriation, ${ }^{7}$ can significantly influence the configuration of absolute and relative prices and their intertemporal dynamics.

Notably, passing from 2005 to 2011 (i.e. reading the graph vertically), the ranking using PPP deflators is more stable than the ranking obtained using XR. This is evident, for example, in the changes in the rankings of Mexico and Brazil, the region's two largest countries. Using XR, Mexico moves from first to fifth places, while Brazil "jumps" from fifth to third place. These changes reflect the variation in relative prices (cf. supra). While Mexico moves from second (2005 round) to fourth place (2011 round) when using PPPs, Brazil remains in fifth place in both years.

7 This last aspect is being studied by the authors in the framework of a research work based on the economic surplus method, applied to the Latin American countries.

\section{Dynamic comparison: evolution of GDP expressed in PPP and in market exchange rates}

One of the chief advantages of calculating GDP series in PPP is that it serves to assess the real contributions made by the countries to the overall regional economy, i.e. the relative size of the respective economies. Figure 2 shows these shares over the period studied for the region's two largest economies (Brazil and Mexico) in relation to total GDP for Latin America (expressed using the series in current prices). ${ }^{8}$

\footnotetext{
8 In the context of this work, the Latin American and Caribbean region includes only those countries for which the relevant calculations could be performed. Argentina and Cuba are therefore not included, for the
} reasons mentioned earlier.

Proportion of GDP of Brazil and Mexico with respect to regional GDP: PPP compared with XR, at current prices

(Percentages)

Brazil

Proportion of regional GDP

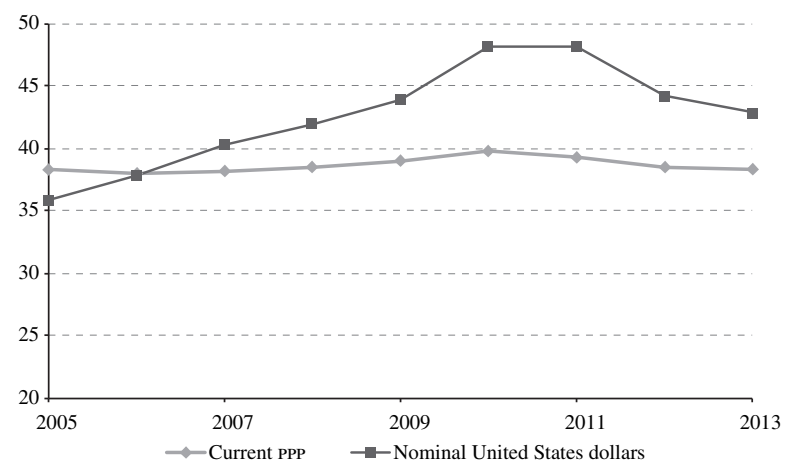

Mexico

Proportion of regional GDP

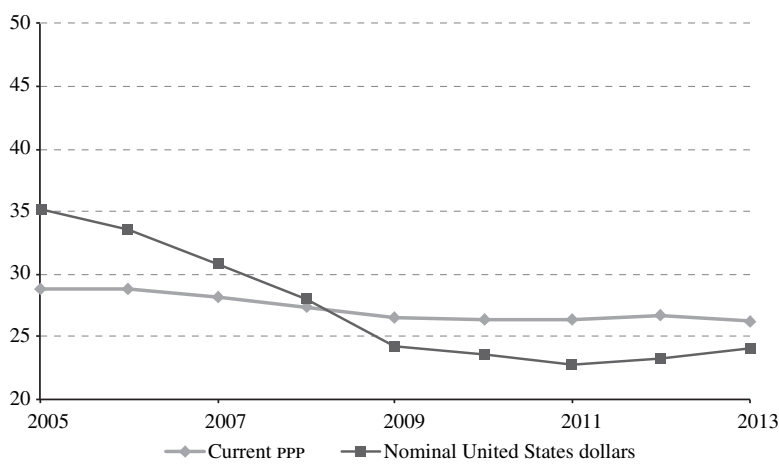

Source: Prepared by the authors, on the basis of Economic Commission for Latin America and the Caribbean (ECLAC), Databases and Statistical Publications (CEPALSTAT) [online] http://estadisticas.cepal.org/cepalstat/WEB_CEPALSTAT/Portada.asp?idioma=i; and World Bank Data Base [online] http://data.worldbank.org/.

Note: XR: Market exchange rate; GDP: Gross domestic product; PPP: Purchasing power parities.

If the shares are calculated in terms of the nominal exchange rate in 2005, Mexico's and Brazil's economies are the same size (each representing $35 \%$ of the regional total), while in PPP terms, the results show that Brazil's economy is significantly larger than Mexico's (38\% of total regional GDP compared with 29\%).

As may be appreciated, Brazil's share in the regional economy grows in nominal terms, from $35 \%$ in 2005 to $43 \%$ of total regional GDP in 2013, peaking at $48 \%$ in 2010 and 2011. However, when the price level is taken into account, the proportion remains between $38 \%$ and $40 \%$ throughout the reference period. This reflects both the rise in price levels in Brazil with respect to the rest of the region's countries, and the large exchange-rate variations registered during the period analysed. 
Mexico's share in nominal terms is similar to Brazil's in 2005 (35\%), then declines sharply, stabilizing at around $21 \%$ as of 2009 . This is because, up to 2007 , Mexico was one of the "most expensive" countries in the region; however, its price level did not rise as much as that of other large Latin American countries. Thus, among the region's five largest economies (in total GDP terms) covered by this study, ${ }^{9}$ Mexico was the most expensive until 2007, but as of 2011 became the "cheapest." At the same time, the PPP series shows Mexico's share taking a slight negative trend, edging down from 29\% in 2005 to $26 \%$ in 2013.

Notably, the shares expressed in PPP terms are more stable and less variable than those expressed in nominal terms. This holds not only for Mexico and Brazil, but for all the countries in the region. ${ }^{10}$

Figure 3 shows the evolution of per capita GDP for Latin America and the Caribbean, as well as the difference between the two subregions in the series expressed in PPP and in market exchange rates (XR).

The series in XR in current dollars show that in 2009 the two subregions began to move closer in terms of per

\footnotetext{
${ }^{9}$ Bolivarian Republic of Venezuela, Brazil, Mexico, Colombia and Chile. 10 The statistical annex presents the GDP series in PPP for the Latin American and Caribbean countries updated with information to January 2015, which can be used to conduct an analysis for each of the countries of the region.
}

capita GDP, and maintained very similar values from 2011 on. In current values (XR), much of this change may be attributed to differences in relative prices.

Figure 4 shows the evolution of the GDP deflators for both subregions in the period. A clear difference in trend may be seen, especially as from 2009, when relative prices accelerate in Latin America compared to the Caribbean. This demonstrates the Balassa-Samuelson effect, because the acceleration occurs in the subregion least affected by the 2009 crisis and, thus, the subregion with larger relative GDP growth.

Comparing the price level index (PLI) with the relative income of each country (see figure 5) measuring on the basis of the per capita nominal GDP index with respect to the regional total, a certain correlation is evident between the two variables. Although the relationship is not very strong, it shows the Penn and the BalassaSamuelson effects, because those countries with a higher income level generally show a higher price level. For this reason, measurement of GDP in PPP tends to show smaller per capita GDP gaps than comparisons done in nominal terms.

The series in constant prices allow a simultaneously intertemporal and interspatial study, unlike the series measured in current PPP in which the results have to be treated as a panel, allowing cross-sectional comparisons for each year available. However, it must be recalled that the methodology used has the disadvantage that both the

FIGURE 3

\section{Latin America and the Caribbean: per capita GDP in dollars at current prices, deflated by PPP and XR, 2005-2013}

Per capita GDP in XR, dollars (current prices)

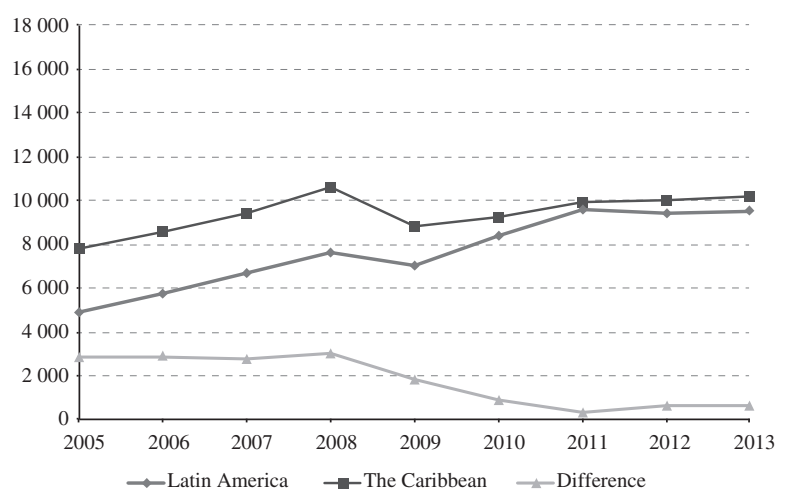

Per capita GDP in XR, current (current PPP)

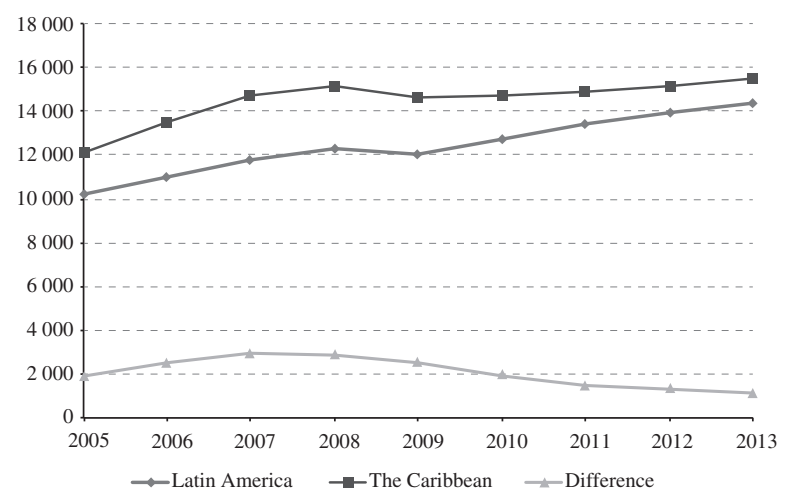

Source: Prepared by the authors, on the basis of Economic Commission for Latin America and the Caribbean (ECLAC), Databases and Statistical Publications (CEPALSTAT) [online] http://estadisticas.cepal.org/cepalstat/WEB_CEPALSTAT/Portada.asp?idioma=i; and World Bank Data Base [online] http://data.worldbank.org/.

Note: PPP: Purchasing power parities; GDP: Gross domestic product; XR: Market exchange rate. 
FIGURE 4

GDP deflators for Latin America and the Caribbean, 2005-2013 $(2005=100)$

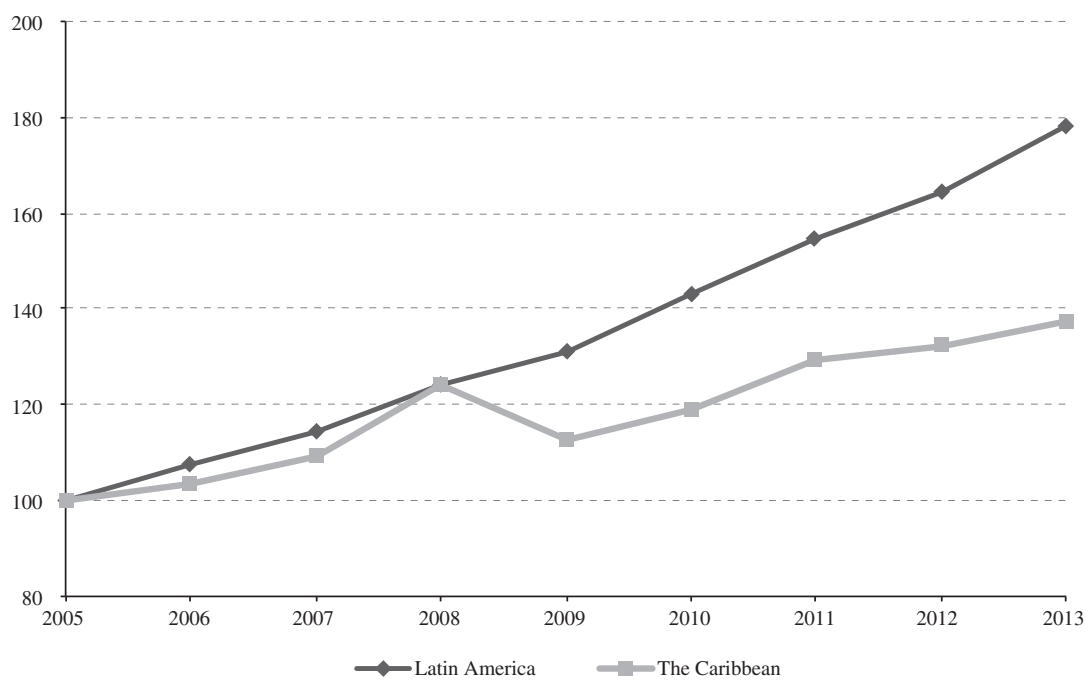

Source: Prepared by the authors, on the basis of Economic Commission for Latin America and the Caribbean (ECLAC), Databases and Statistical Publications (CEPALSTAT) [online] http://estadisticas.cepal.org/cepalstat/WEB_CEPALSTAT/Portada.asp?idioma=i; and World Bank Data Base [online] http://data.worldbank.org/.

Note: GDP: Gross domestic product.

FIGURE 5

Latin America and the Caribbean: relation between level of per capita GDP and price level, 2011

(Horizontal axis, region $=100$; vertical axis, United States $=100)$

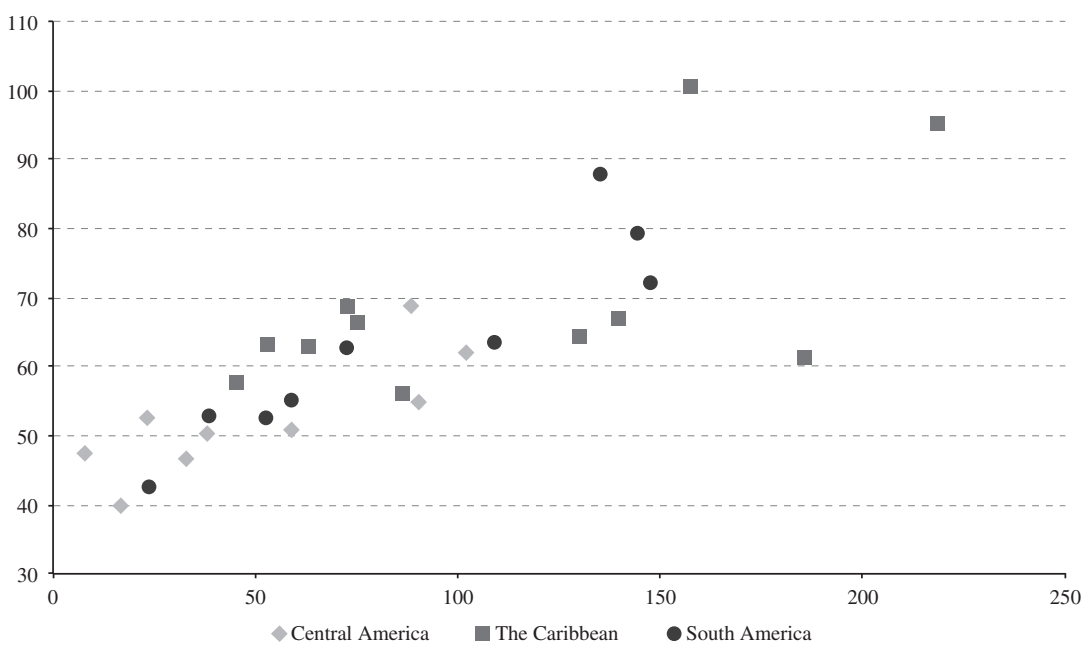

Source: Prepared by the authors, on the basis of Economic Commission for Latin America and the Caribbean (ECLAC), Databases and Statistical Publications (CEPALSTAT) [online] http://estadisticas.cepal.org/cepalstat/WEB_CEPALSTAT/Portada.asp?idioma=i; and World Bank Data Base [online] http://data.worldbank.org/.

Note: GDP: Gross domestic product. 
levels of series and the rates of regional or subregional growth can vary significantly depending on the base year chosen and the countries included in the analysis. ${ }^{11}$

11 The non-participation of a country as large as Argentina in the latest ICP round has obvious repercussions on the results of the study, in terms of both weighting and the level and evolution of regional PPPs. In this respect, Epstein and Marconi (2014) offer an analysis of the effect of incorporating Argentina into the calculations.
The growth rates for the countries throughout the period are not analysed, because they are calculated on the basis of the constant price series published by the national institutions responsible for preparing the national accounts. Conversely, it is worth analysing the results at the regional and subregional levels. Figure 6 shows per capita GDP expressed in PPP at constant 2010 prices.

FIGURE 6
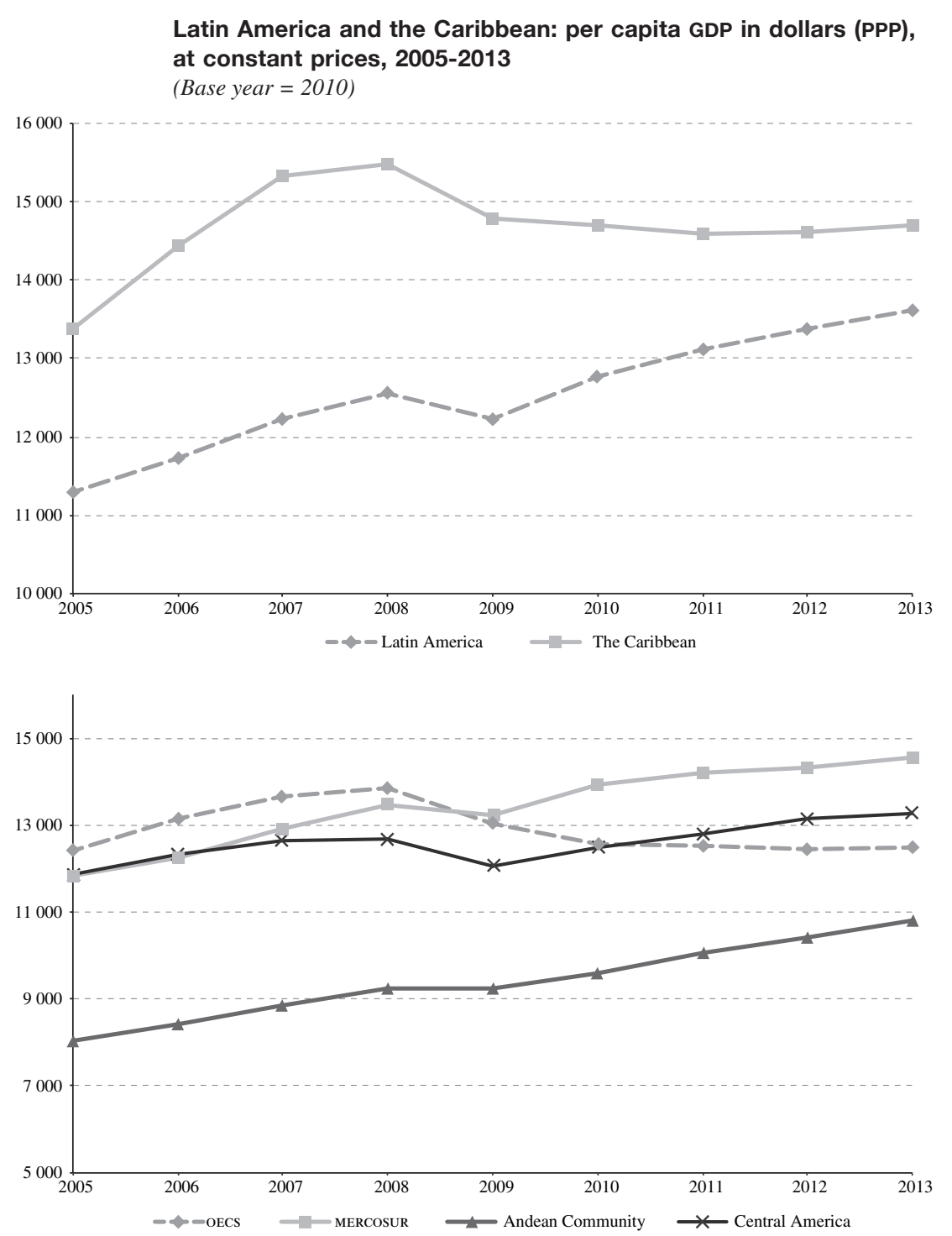

Source: Prepared by the authors, on the basis of Economic Commission for Latin America and the Caribbean (ECLAC), Databases and Statistical Publications (CEPALSTAT) [online] http://estadisticas.cepal.org/cepalstat/WEB_CEPALSTAT/Portada.asp?idioma=i; and World Bank Data Base [online] http://data.worldbank.org/.

Note: oEcs: Antigua and Barbuda, Dominica, Grenada, Saint Lucia, Saint Kitts and Nevis, and Saint Vincent and the Grenadines. MERCosur: Brazil, Paraguay, Uruguay and Venezuela (Bolivarian Republic of). Andean Community: Bolivia (Plurinational State of), Colombia, Ecuador and Peru. Central America: Costa Rica, Dominican Republic, El Salvador, Guatemala, Haiti, Honduras, Mexico, Nicaragua and Panama. GDP: Gross domestic product. 
The per capita GDP series in constant PPP for Latin America and the Caribbean are very similar to the series in current PPP (see figure 3). This is because, given the method of extrapolation of the PPPs used with implicit deflators, the current PPPs include the effect of relative prices vis-à-vis the United States.

Analysis of the GDP series in constant PPPs for the four subregions shows that the effect of the 2009 crisis was heavier for oEcs (Antigua and Barbuda, Dominica, Grenada, Saint Lucia, Saint Kitts and Nevis, and Saint Vincent and the Grenadines) than the rest of the countries. In fact, the per capita value at the start of the period (2005) is similar to that of 2013 (US\$ 12,413 and US\$ 12,499, respectively). That subregion's GDP surpassed that of the other three subregions in 2005, but had moved down to third place in 2013, exceeding only that of the Andean Community. Conversely, the Southern Common Market (MERCOSUR) achieved significant growth during the period (a cumulative 23\%), moving from US\$ 11,835 in 2005 to US\$ 14,539 in 2013, making it the subregion with the highest per capita GDP (in constant 2010 PPP).

Central America also felt the effects of the crisis. Its per capita GDP was US\$11,868 in 2005, very similar to that of MERCOSUR, and registered cumulative growth of $11 \%$ between 2005 and 2013. Lastly, the Andean Community was the subregion with the lowest per capita GDP growth in constant PPP terms, despite showing the fastest growth, from US\$ 8,040 in 2005 to US\$ 10,814 in 2013 (a cumulative rise of $35 \%$ ).

Finally, the differences between the series expressed in market exchange rates and those in PPP may be attributed to the evolution of the price level index per the International Comparison Programme (PLI). Table 1 shows PLI values with respect to total GDP for the countries of the region, expressed in relation to the price level of the United States.

Table 1 shows both the evolution of the PLI in relation to United States prices (the horizontal comparison in the table) and how the countries relate to each other in any given year (vertical comparison).

Analysing the evolution of the PLI, it may be seen that South America (cumulative 60\%) is the subregion whose prices rose most with respect to United States prices, with PLI variations of between $37 \%$ and $90 \%$ over the period in cumulative terms. Uruguay's price level, for example, went from less than half of that of the United States in 2005 to over $80 \%$ in 2013 . The analysis by GDP component suggests this is due to a strong increase in the government expenditure deflator (wage increase) in Uruguay, in comparison with other countries.
Central America (6\%) showed a large increase, though not on the same scale as South America, with gains in price levels varying from $15 \%$ and $50 \%$ in cumulative terms over the period with respect to United States prices. Mexico, El Salvador and the Dominican Republic are exceptions, with variations of $4 \%, 8 \%$ and $-2 \%$, respectively.

Finally, the Caribbean (2\%) shows small increases and even some decreases, with the exception of Suriname, whose price movements are more similar to those of South America.

With regard to the "vertical" comparison between countries, the Caribbean shows very similar price levels, with the exception of the Bahamas and Barbados, which are in fact more expensive than the United States in several years of the period analysed (PLI over 100). The Central America group also shows relatively similar levels, except for Costa Rica and Mexico, which are the most expensive countries of the subregion towards the end of the period 2005-2013. In this regard, Costa Rica is the country to have changed its PLI ranking most, from fourth place in 2005 to first place in 2013, easily passing Mexico (by over ten percentage points). As in the case of Uruguay, the explanation for this lies in policies adopted to increase public sector wages (see figure 7).

South America is the most uneven grouping in terms of relative prices. For example, Brazil, Colombia and Uruguay had similar price levels in 2005, but by the end of the period they were very different (with gaps of around 20 percentage points in 2013). Chile was the most expensive country in the subregion in 2005, surpassing the Bolivarian Republic of Venezuela by almost ten percentage points in this regard. But in 2013, price levels in Chile and the Bolivarian Republic of Venezuela were both around $70 \%$ of United States prices, and they were, respectively, the third and fourth most expensive countries in the subregion, after Uruguay and Brazil.

The differences between the various subregions are the consequence of two main factors: (i) prices in the Caribbean (and, to a lesser extent, in Central America) are more strongly tied than prices in South America to United States prices, and (ii) the exchange-rate effect, where exchange rates in the Caribbean are much more stable than those in Latin America, although there are a few exceptions, such as the cases of Jamaica and Suriname or the Latin American countries with dollarized economies (Ecuador, Panama and El Salvador). The first factor applies mainly to trend differences (the horizontal or temporal comparison), while the second partially explains both types of differences, trend and geographical (or vertical). 
TABLE 1

Price level index, 2005-2013

(United States $=100)$

\begin{tabular}{|c|c|c|c|c|c|c|c|c|c|c|}
\hline Region or country & 2005 & 2006 & 2007 & 2008 & 2009 & 2010 & 2011 & 2012 & 2013 & $\begin{array}{c}\text { Percentage } \\
\text { variation } \\
2005-2013\end{array}$ \\
\hline \multicolumn{11}{|l|}{ Central America } \\
\hline Costa Rica & 48.8 & 49.1 & 51.8 & 56.1 & 55.4 & 64.4 & 68.6 & 70.5 & 73.4 & 50 \\
\hline Dominican Republic & 49.0 & 45.7 & 47.1 & 49.0 & 48.4 & 49.3 & 50.9 & 50.5 & 48.2 & -2 \\
\hline El Salvador & 45.8 & 46.4 & 47.2 & 48.7 & 48.1 & 48.6 & 50.3 & 49.9 & 49.3 & 8 \\
\hline Guatemala & 37.2 & 38.1 & 39.4 & 42.9 & 40.8 & 43.0 & 46.6 & 47.0 & 47.7 & 28 \\
\hline Haiti & 32.2 & 35.9 & 41.5 & 43.3 & 42.3 & 45.6 & 47.2 & 47.1 & 47.8 & 48 \\
\hline Honduras & 40.2 & 40.9 & 42.5 & 44.9 & 48.0 & 49.7 & 52.5 & 51.7 & 49.6 & 23 \\
\hline Mexico & 58.7 & 60.5 & 61.7 & 63.1 & 53.3 & 58.8 & 61.8 & 59.1 & 61.0 & 4 \\
\hline Nicaragua & 34.2 & 34.2 & 34.7 & 37.7 & 38.0 & 38.7 & 39.8 & 40.0 & 39.9 & 17 \\
\hline \multirow[t]{2}{*}{ Panama } & 49.4 & 48.9 & 49.1 & 51.9 & 51.7 & 53.6 & 54.7 & 55.6 & 56.8 & 15 \\
\hline & 56.0 & 57.5 & 58.6 & 60.2 & 52.1 & 57.0 & 59.9 & 57.8 & 59.3 & 6 \\
\hline \multicolumn{11}{|l|}{ The Caribbean } \\
\hline Antigua and Barbuda & 63.4 & 61.7 & 62.3 & 63.9 & 64.5 & 64.6 & 64.1 & 64.6 & 63.5 & 0 \\
\hline Bahamas & 103.5 & 101.2 & 101.5 & 101.0 & 99.2 & 97.6 & 94.9 & 95.6 & 95.9 & -7 \\
\hline Barbados & 105.3 & 107.2 & 107.4 & 105.7 & 110.6 & 105.2 & 100.8 & 95.6 & 96.5 & -8 \\
\hline Belize & 56.1 & 56.9 & 58.1 & 58.5 & 56.3 & 56.3 & 57.5 & 57.6 & 57.7 & 3 \\
\hline Dominica & 67.3 & 66.9 & 66.2 & 66.1 & 70.6 & 68.2 & 68.9 & 69.5 & 69.4 & 3 \\
\hline Grenada & 63.8 & 64.8 & 64.5 & 68.3 & 67.8 & 67.3 & 66.0 & 67.4 & 67.8 & 6 \\
\hline Jamaica & 63.0 & 63.1 & 56.3 & 59.6 & 54.7 & 59.9 & 63.0 & 63.9 & 60.2 & -4 \\
\hline Saint Kitts and Nevis & 58.9 & 63.2 & 64.4 & 65.2 & 66.1 & 65.9 & 66.8 & 66.8 & 66.1 & 12 \\
\hline Saint Lucia & 62.5 & 63.9 & 67.1 & 65.1 & 64.5 & 68.1 & 68.3 & 68.9 & 69.9 & 12 \\
\hline Saint Vincent and the Grenadines & 61.0 & 60.9 & 64.3 & 63.1 & 62.1 & 64.1 & 62.6 & 62.3 & 61.8 & 1 \\
\hline Suriname & 44.3 & 45.1 & 46.8 & 53.0 & 56.0 & 59.3 & 55.9 & 60.4 & 61.1 & 38 \\
\hline \multirow[t]{2}{*}{ Trinidad and Tobago } & 54.0 & 52.7 & 57.9 & 70.7 & 50.5 & 53.4 & 61.4 & 58.8 & 60.0 & 11 \\
\hline & 64.1 & 63.1 & 63.6 & 70.1 & 60.5 & 63.0 & 66.5 & 65.9 & 65.5 & 2 \\
\hline \multicolumn{11}{|l|}{ South America } \\
\hline Bolivia (Plurinational State of) & 25.0 & 27.8 & 29.7 & 34.8 & 34.8 & 37.4 & 42.5 & 44.8 & 46.8 & 87 \\
\hline Brazil & 44.9 & 51.8 & 59.7 & 67.3 & 65.7 & 79.8 & 87.9 & 77.7 & 74.5 & 66 \\
\hline Chile & 50.3 & 57.9 & 60.4 & 59.4 & 57.0 & 67.4 & 72.0 & 71.2 & 70.1 & 39 \\
\hline Colombia & 41.1 & 41.4 & 48.1 & 53.6 & 50.0 & 58.5 & 62.9 & 65.5 & 63.0 & 54 \\
\hline Ecuador & 39.4 & 41.3 & 42.9 & 47.9 & 47.9 & 50.8 & 52.6 & 54.3 & 55.1 & 40 \\
\hline Paraguay & 27.7 & 31.2 & 37.4 & 46.2 & 41.1 & 45.2 & 53.1 & 51.8 & 52.5 & 90 \\
\hline Peru & 40.9 & 43.1 & 44.5 & 47.2 & 46.3 & 51.5 & 55.2 & 57.7 & 55.9 & 37 \\
\hline Uruguay & 46.2 & 48.6 & 53.1 & 63.1 & 61.3 & 71.4 & 79.1 & 79.4 & 83.4 & 80 \\
\hline \multirow{2}{*}{ Venezuela (Bolivarian Republic of) } & 40.8 & 45.4 & 51.1 & 65.2 & 69.8 & 50.9 & 63.3 & 70.9 & 69.7 & 71 \\
\hline & 43.7 & 49.1 & 55.5 & 62.6 & 61.4 & 70.0 & 77.3 & 72.4 & 70.0 & 60 \\
\hline Latin America and the Caribbean & 48.2 & 52.2 & 56.7 & 61.9 & 58.4 & 65.7 & 71.5 & 67.5 & 66.5 & 38 \\
\hline
\end{tabular}

Source: Prepared by the authors, on the basis of Economic Commission for Latin America and the Caribbean (ECLAC), Databases and Statistical Publications (CEPALSTAT) [online] http://estadisticas.cepal.org/cepalstat/WEB_CEPALSTAT/Portada.asp?idioma=i; and World Bank Data Base [online] http://data.worldbank.org/. 
Price level index by subregion, 2005-2013

(United States $=100)$

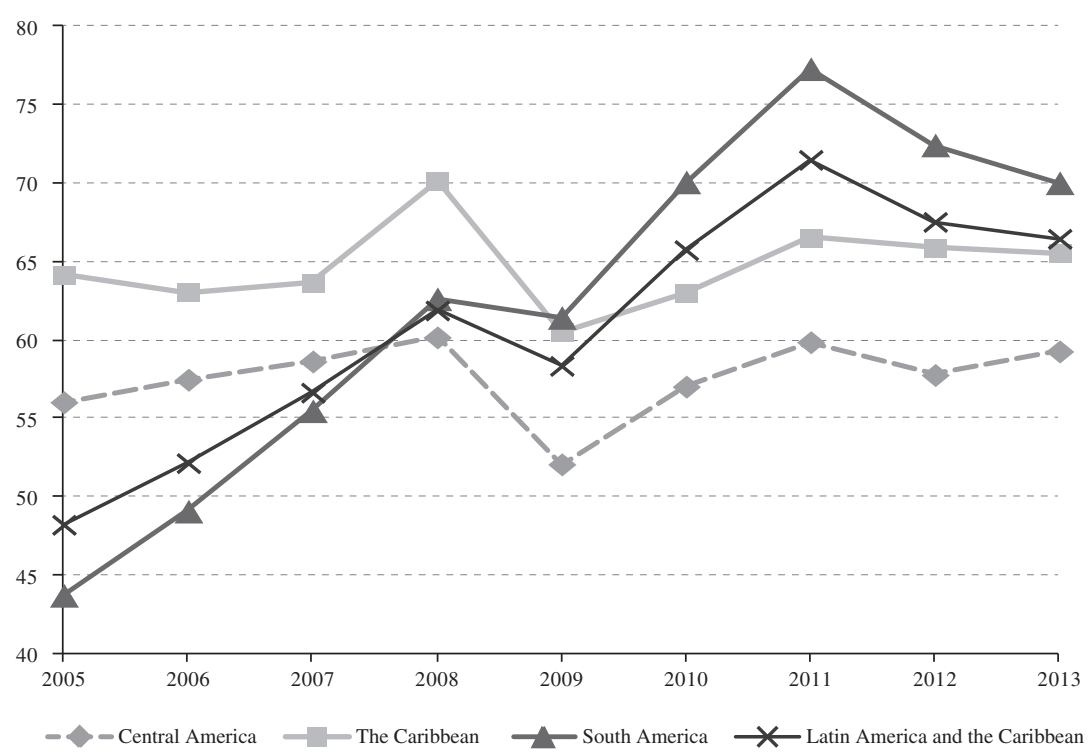

Source: Prepared by the authors, on the basis of Economic Commission for Latin America and the Caribbean (ECLAC), Databases and Statistical Publications (CEPALSTAT) [online] http://estadisticas.cepal.org/cepalstat/WEB_CEPALSTAT/Portada.asp?idioma=i; and World Bank Data Base [online] http://data.worldbank.org/.

\section{Comparison of the results at the aggregate level and by component (series at current prices)}

As noted earlier, one of the objectives of the exercise was to compare the results obtained at the aggregate level of GDP and in the disaggregation by component. The exercise by component was carried out for the nine South American countries included in this study and Mexico, being the countries of the region that participated in the 2005 and 2011 rounds and, thus, offering a basis for comparison of the estimates with respect to the benchmark. Table 2 compares the results obtained from the two methods, i.e. comparing the calculations at the GDP level with those performed at the component level.

It should be noted that differences of more than $3 \%$ arise even for the base year 2011 (column shown in grey in table 2). A priori, these two PPPs could be expected to be the same; however, there are differences in the weightings of the components in the national accounts, both for the Latin American countries and for the benchmark country, with respect to those used in the ICP in 2011, which partly explains the disparities. Furthermore, the multilateral aggregation was applied to the component estimates for only 11 of the countries involved (the ten Latin American countries plus the United States), while the ICP operation included the 16 Latin American countries participating in the Programme, except Chile and Mexico, which were included in the OECD "region". 12

As is evident in table 2, there are significant differences which tend to grow broader at the tails of the series. This is the case of Brazil, Colombia, Ecuador, Peru and Uruguay, whose PPPs are similar in 2011, with the differences growing the further from that year the estimate is taken.

It should be noted that the PPPs estimated by components tend to show higher values than those estimated at the GDP level. The Bolivarian Republic of Venezuela and Chile show more irregular differences owing to changes in the prices of their main export commodities (oil and copper, respectively). ${ }^{13}$ This

12 For further information on these methodologies, see World Bank (2013).

13 In 2008 there was a sharp fall in the price of oil, which affected not only Venezuela, but also Ecuador (see figure 8 ). The copper price also saw significant falls in 2005 and in 2008-2009. 
TABLE 2

Estimates of PPP at the GDP level and by component, in monetary units of each country per US\$1, 2005-2013

\begin{tabular}{|c|c|c|c|c|c|c|c|c|c|c|}
\hline Country & Estimate & 2005 & 2006 & 2007 & 2008 & 2009 & 2010 & 2011 & 2012 & 2013 \\
\hline \multirow{3}{*}{$\begin{array}{l}\text { Bolivia } \\
\text { (Plurinational } \\
\text { State of) }\end{array}$} & GDP level & 2.02 & 2.23 & 2.33 & 2.52 & 2.44 & 2.62 & 2.95 & 3.10 & 3.23 \\
\hline & Components & 2.22 & 2.40 & 2.54 & 2.65 & 2.68 & 2.78 & 3.05 & 3.16 & 3.34 \\
\hline & Percentage difference & 10 & 7.6 & 8.9 & 5.1 & 9.7 & 5.9 & 3.4 & 1.9 & 3.2 \\
\hline \multirow[t]{3}{*}{ Brazil } & GDP level & 1.09 & 1.13 & 1.16 & 1.23 & 1.31 & 1.40 & 1.47 & 1.52 & 1.61 \\
\hline & Components & 1.14 & 1.17 & 1.20 & 1.25 & 1.35 & 1.42 & 1.47 & 1.54 & 1.64 \\
\hline & Percentage difference & 4.6 & 3.5 & 3.2 & 1.3 & 3.1 & 1.1 & 0.1 & 1.6 & 2.2 \\
\hline \multirow[t]{3}{*}{ Chile } & GDP level & 281.66 & 307.21 & 315.56 & 310.23 & 319.72 & 343.75 & 348.02 & 346.33 & 347.14 \\
\hline & Components & 305.38 & 304.00 & 310.57 & 331.14 & 339.08 & 343.77 & 349.92 & 355.75 & 362.25 \\
\hline & Percentage difference & 8.4 & -1.0 & -1.6 & 6.7 & 6.1 & 0.0 & 0.5 & 2.7 & 4.4 \\
\hline \multirow[t]{3}{*}{ Colombia } & GDP level & 952.72 & 977.70 & 1000.36 & 1055.24 & 1082.98 & 1111.17 & 1161.91 & 1177.60 & 1177.98 \\
\hline & Components & 1016.56 & 1038.43 & 1056.63 & 1085.38 & 1139.19 & 1148.59 & 1176.76 & 1192.26 & 1203.58 \\
\hline & Percentage difference & 6.7 & 6.2 & 5.6 & 2.9 & 5.2 & 3.4 & 1.3 & 1.2 & 2.2 \\
\hline \multirow[t]{3}{*}{ Ecuador } & GDP level & 0.39 & 0.41 & 0.43 & 0.48 & 0.48 & 0.51 & 0.53 & 0.54 & 0.55 \\
\hline & Components & 0.42 & 0.44 & 0.44 & 0.47 & 0.50 & 0.52 & 0.53 & 0.55 & 0.56 \\
\hline & Percentage difference & 7.3 & 5.4 & 3.1 & -0.9 & 4.5 & 2.6 & 1.7 & 2.1 & 2.1 \\
\hline \multirow[t]{3}{*}{ Mexico } & GDP level & 6.40 & 6.60 & 6.75 & 7.02 & 7.20 & 7.43 & 7.67 & 7.78 & 7.79 \\
\hline & Components & 6.59 & 6.69 & 6.88 & 7.14 & 7.52 & 7.75 & 7.91 & 8.11 & 8.20 \\
\hline & Percentage difference & 3.0 & 1.4 & 1.9 & 1.7 & 4.4 & 4.2 & 3.0 & 4.2 & 5.3 \\
\hline \multirow[t]{3}{*}{ Paraguay } & GDP level & 1708.76 & 1758.67 & 1880.39 & 2016.39 & 2042.07 & 2140.51 & 2227.34 & 2291.93 & 2268.09 \\
\hline & Components & 1753.20 & 1866.89 & 1952.31 & 2100.37 & 2073.83 & 2210.40 & 2274.37 & 2281.62 & 2360.90 \\
\hline & Percentage difference & 2.6 & 6.2 & 3.8 & 4.2 & 1.6 & 3.3 & 2.1 & -0.4 & 4.1 \\
\hline \multirow[t]{3}{*}{ Peru } & GDP level & 1.35 & 1.41 & 1.39 & 1.38 & 1.40 & 1.46 & 1.52 & 1.52 & 1.51 \\
\hline & Components & 1.49 & 1.48 & 1.47 & 1.49 & 1.52 & 1.52 & 1.55 & 1.57 & 1.60 \\
\hline & Percentage difference & 10.1 & 4.8 & 5.4 & 7.6 & 8.8 & 4.5 & 1.8 & 3.0 & 5.7 \\
\hline \multirow[t]{3}{*}{ Uruguay } & GDP level & 11.32 & 11.70 & 12.47 & 13.21 & 13.84 & 14.31 & 15.28 & 16.12 & 17.09 \\
\hline & Components & 11.81 & 12.30 & 13.08 & 13.55 & 14.42 & 14.66 & 15.33 & 16.19 & 17.11 \\
\hline & Percentage difference & 4.3 & 5.1 & 4.9 & 2.5 & 4.1 & 2.4 & 0.3 & 0.4 & 0.1 \\
\hline \multirow{3}{*}{$\begin{array}{l}\text { Venezuela } \\
\text { (Bolivarian } \\
\text { Republic of) }\end{array}$} & GDP level & 0.85 & 0.98 & 1.10 & 1.40 & 1.50 & 2.16 & 2.71 & 3.04 & 4.21 \\
\hline & Components & 0.89 & 0.98 & 1.11 & 1.35 & 1.74 & 2.18 & 2.67 & 3.10 & 4.70 \\
\hline & Percentage difference & 3.8 & 0.6 & 1.0 & -3.6 & 16.1 & 0.9 & -1.6 & 2.0 & 11.5 \\
\hline
\end{tabular}

Source: Prepared by the authors, on the basis of Economic Commission for Latin America and the Caribbean (ECLAC), Databases and Statistical Publications (CEPALSTAT) [online] http://estadisticas.cepal.org/cepalstat/WEB_CEPALSTAT/Portada.asp?idioma=i; and World Bank Data Base [online] http://data.worldbank.org/.

Note: PPP: Purchasing power parities; GDP: Gross domestic product.

is mainly because the component method uses the exchange rate for exports and imports as a benchmark PPP. The rationale for this practice is that commodity prices - in the absence of transport costs, insurance and taxes, among others - should be the same in dollars for all the countries, such that relative prices (and PPPs), should be given by the exchange rate. ${ }^{14}$ Extrapolating

14 The situation with services (tourism, for example) is different and much more complex; for the sake of simplicity the ICP uses PPP exchange rates as a benchmark.
PPPs using the aggregate GDP deflator incorporates the effect of changes in the prices of the countries' export and import baskets (because they are involved in the calculation of the GDP deflator), which is not necessarily reflected in the exchange rates used in the estimation by component.

Figure 8 reports the per capita GDP series in current PPP, estimated at the aggregate level and by component.

In general, the values of per capita GDP in PPP estimated by component are smaller than those estimated at the aggregate level. These differences may be quite 
large for some countries, as much as $10 \%$ of total per capita GDP for some years. This is the case of the Plurinational State of Bolivia.

For the reasons explained, the Bolivarian Republic of Venezuela and Chile, and to a lesser extent Ecuador, present some rather different traits, with per capita GDP differences that can change sign depending on the method used. For example, for the Bolivarian Republic of Venezuela, the components methods yields a per capita GDP in PPP almost US\$ 650 less in 2008, while in 2009 the aggregate method yields a value higher by almost US\$2,300.

The components method also shows a stronger effect of the 2009 crisis on per capita GDP in PPP. This is apparent in figure 8 for all the countries analysed, with the exception of Paraguay.

Per capita GDP in PPP estimated by the aggregate and components methods, in dollars, 2005-2013
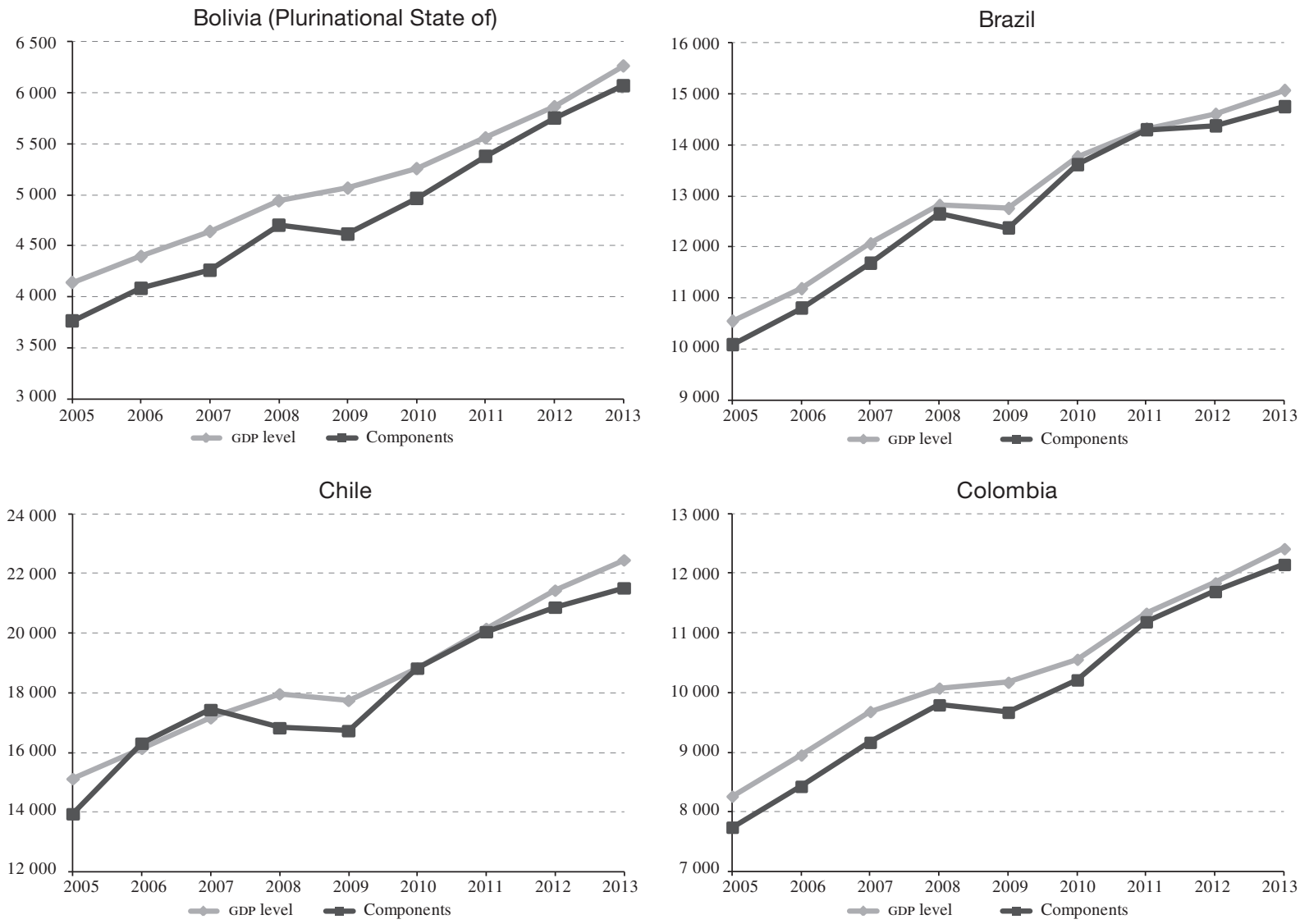
Figure 8 (concluded)

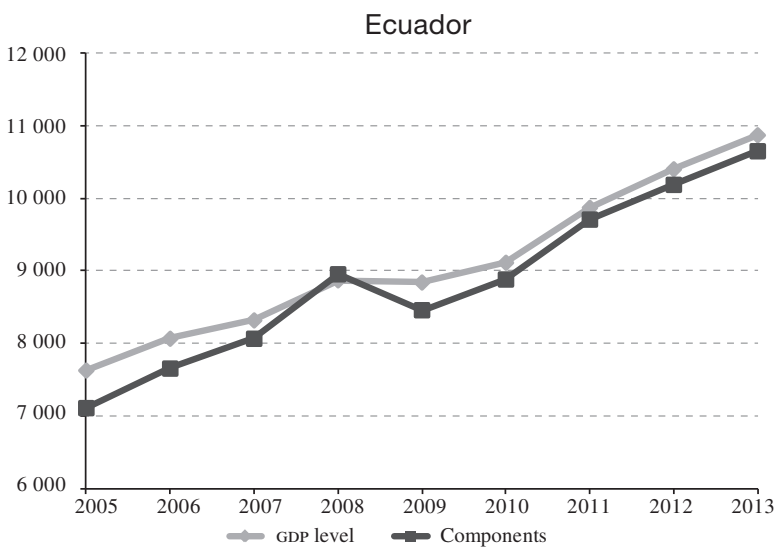

Paraguay

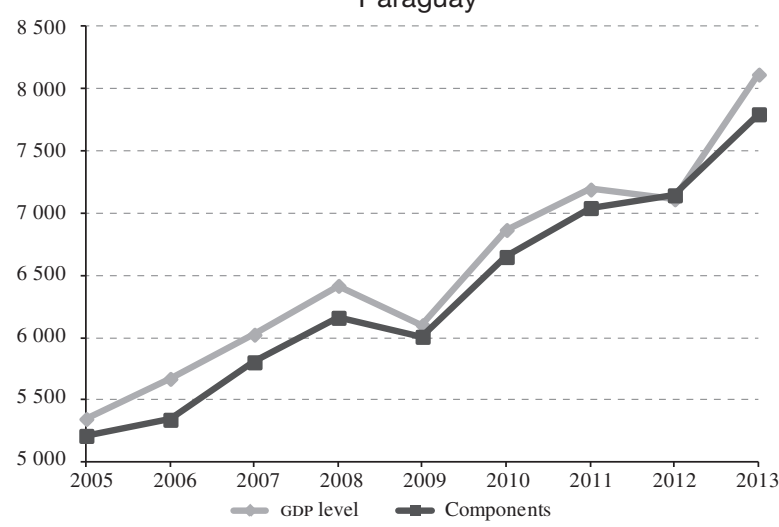

Uruguay

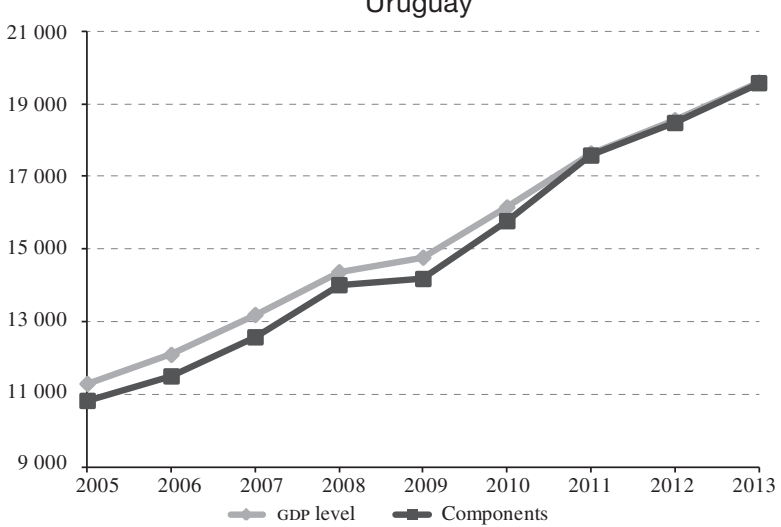

Mexico

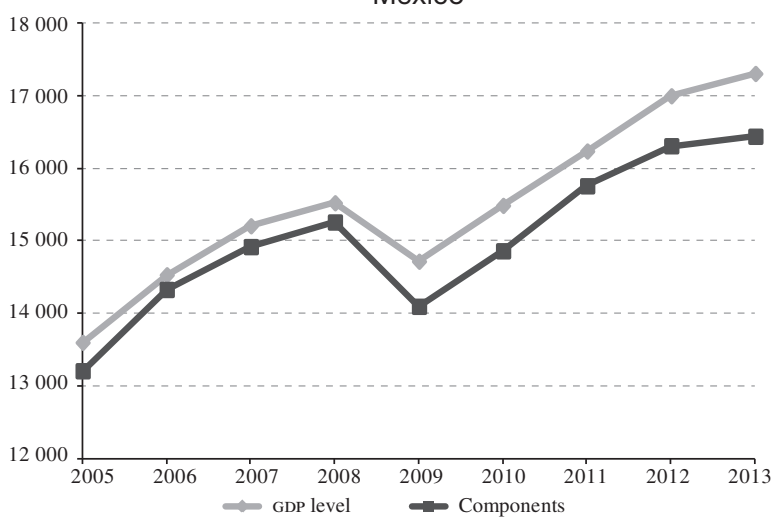

Peru

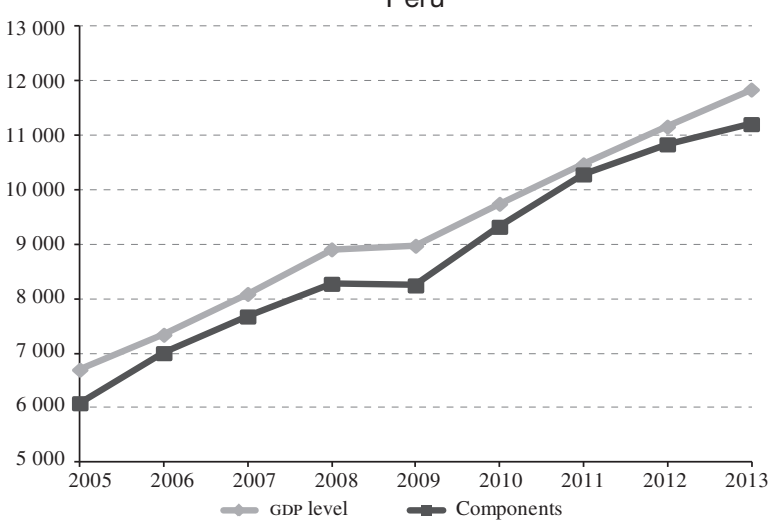

Venezuela (Bolivarian Republic of)

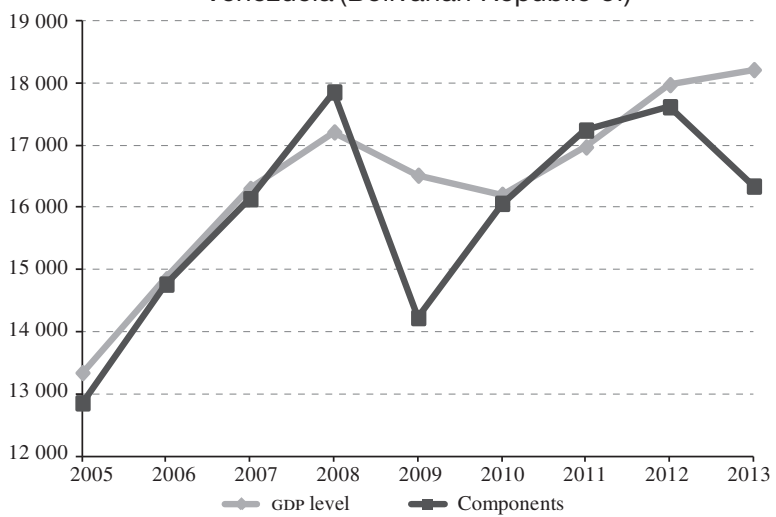

Source: Prepared by the authors, on the basis of Economic Commission for Latin America and the Caribbean (ECLAC), Databases and Statistical Publications (CEPALSTAT) [online] http://estadisticas.cepal.org/cepalstat/WEB_CEPALSTAT/Portada.asp?idioma=i; and World Bank Data Base [online] http://data.worldbank.org/.

Note: PPP: Purchasing power parities; GDP: Gross domestic product. 
Finally, it is important to mention that, given the non-additive nature of the EKS method used by ICP and in this exercise, a statistical discrepancy arises between total real GDP in PPP and the sum of the components in PPP, which hinders the calculation of the real share of the components in GDP and the estimation of specific aggregates, such as domestic absorption. The size of this discrepancy varies markedly between the countries, with values of less than $1 \%$ for Colombia over the whole period and differences of almost $15 \%$ of total GDP in the Bolivarian Republic of Venezuela for 2005.

\section{A crucial comparison: estimates versus benchmark}

A comparison of the results obtained at the aggregate level and the figures calculated by component does not show which of the two is "closer to the truth," although from the theoretical point of view the components methods should be used, as recommended by SNA 2008 .

A crucial comparison for verifying the goodness of fit of the estimation methods is to compare the results obtained with the estimates yielded in the framework of an ICP round (benchmark). Since the ICP calculation is based on comparison of prices surveyed at the individual product level, with abundant, detailed information, it may logically be assumed that these results are of better quality than any extrapolation performed using deflators. This section compares the results of the 2005 ICP round with the PPPs obtained by the two extrapolation methods for that year. The results are presented in table 3 .

As may be appreciated, the PPPs obtained using the components method show closer values to the reference year 2005 for all the countries. For some countries, such as Ecuador, Peru and the Plurinational State of Bolivia, the PPPs by component show values very close to the reference period, with differences of less than $1 \%$, while those estimated at the aggregate GDP level show larger differences of between $6 \%$ and $10 \%$. In the case of the Bolivarian Republic of Venezuela, Brazil, Paraguay and Uruguay, the PPPs estimated differ notably from those obtained in the 2005 ICP round, which speaks to the weakness of extrapolation/retropolation methods.

It is also important to bear in mind that the results of the ICP for 2005 are also estimates and, as such, may have biases. In this regard, Deaton and Aten (2014) argue that PPPS calculated in the context of the 2005 round of ICP, especially those referring to household consumption, are overestimated owing mainly to the methodology used to link the different regions. These authors find that the overestimates are largest for the regions of Asia, Western Asia and Africa, although they also affect Latin America. In that case the "real" PPPs would be closer to the extrapolations performed in this study.

TABLE 3

Comparison of PPPs calculated in the $\mathbf{2 0 0 5}$ round of ICP with the estimates obtained using extra/retropolation, 2005

\begin{tabular}{|c|c|c|c|c|c|}
\hline Country & PPP ICP 2005 & GDP level & Components & $\begin{array}{c}\text { Difference by } \\
\text { GDP level }\end{array}$ & $\begin{array}{l}\text { Difference by } \\
\text { Components }\end{array}$ \\
\hline Bolivia (Plurinational State of) & 2.23 & 2.02 & 2.22 & $-9.4 \%$ & $-0.4 \%$ \\
\hline Brazil & 1.36 & 1.09 & 1.14 & $-19.6 \%$ & $-15.9 \%$ \\
\hline Chile & 333.69 & 281.66 & 305.38 & $-15.6 \%$ & $-8.5 \%$ \\
\hline Colombia & 1081.95 & 952.72 & 1016.56 & $-11.9 \%$ & $-6.0 \%$ \\
\hline Ecuador & 0.42 & 0.39 & 0.42 & $-6.1 \%$ & $0.7 \%$ \\
\hline Paraguay & 2006.83 & 1708.76 & 1753.20 & $-14.9 \%$ & $-12.6 \%$ \\
\hline Peru & 1.49 & 1.35 & 1.49 & $-9.4 \%$ & $-0.3 \%$ \\
\hline Uruguay & 13.28 & 11.32 & 11.81 & $-14.8 \%$ & $-11.1 \%$ \\
\hline Venezuela (Bolivarian Republic of $)^{\mathrm{a}}$ & 1.15 & 0.85 & 0.89 & $-26.0 \%$ & $-23.2 \%$ \\
\hline
\end{tabular}

Source: Prepared by the authors, on the basis of Economic Commission for Latin America and the Caribbean (ECLAC), Databases and Statistical Publications (CEPALSTAT) [online] http://estadisticas.cepal.org/cepalstat/WEB_CEPALSTAT/Portada.asp?idioma=i; and World Bank Data Base [online] http://data.worldbank.org/.

Note: PPP: Purchasing power parities; ICP: International Comparison Programme.

a The PPPs for the Bolivarian Republic of Venezuela for the 2005 ICP were divided by 1,000, owing to the exchange rate implemented in 2008, when the currency changed from the bolívar to the bolívar fuerte, at a rate of 1,000 to 1 . 


\section{IV}

\section{Final remarks}

This work examined different options for obtaining series of PPPS without incurring additional costs.

There are a number of limitations in relation to the availability of information, especially for those countries which did not participate directly in the 2005 or 2011 rounds of the International Comparison Programme (ICP). There are also methodological limitations, because despite having followed the recommendations of SNA 2008 to estimate the PPP series, the results may have significant biases arising from a "structure effect." These biases can be reduced by extrapolating at more disaggregated levels, as in the components method. However, it is not viable to use this method for the countries of the Caribbean, most of which do not compile GDP by type of expenditure at constant prices and, thus, do not have deflators by type of expenditure.

In order to improve the results and mitigate estimate biases, it is therefore necessary to perform the calculations by component, and even at a lower level in the case of household consumption, which merits a special analysis owing to its large share of GDP.

This article has pointed to other factors that may introduce discrepancies into the estimates and the benchmark values obtained for the reference years. A first difference lies in the fact that PPP rates are calculated on a multilateral basis, meaning that a change in the information of one of the countries involved affects the PPP estimates of all the countries. In this regard, if the group of countries participating in the calculation is not the same, this may have significant effects in the end results.

In the case of the components method, the results include only ten countries of Latin America and the United States as a benchmark, for reasons of comparability and availability of information for the 2005 and 2011 rounds of ICP.

The second difference occurs because of methodological differences implemented between the 2005 and 2011 rounds of ICP in the linking of the regional PPP calculations. The methodology used to link the regional results changed significantly between the two rounds: in 2005 a ring methodology was used, whereby only 18 countries participated in the global calculation in representation of all the participating regions. Conversely, the 2011 round adopted a common global basket using information from all the participating countries.

According to Deaton and Aten (2014), this methodological difference is responsible for much of the widespread overestimation of PPP for household consumption (and, thus, of GDP) in the 2005 round. These authors find that the overestimation is chiefly due to two factors: (i) the inclusion of products in the "ring basket" that were available only in developed countries and that were therefore expensive in poorer countries, and (ii) the use of average weightings in the ring methodology, which led to some products that were expensive but had little weight in a developing country's expenditure (such as air transport) weighing more in the ring calculation.

Despite the limitations mentioned, the series prepared for this work observe international standards and recommendations and may be used to conduct comparative studies between countries. From an analytical perspective, these results are an important input for proving the interpretative hypothesis on differences in the level and evolution of prices in the countries of the region, including gaps between them in trade and tariff openness and in productivity, and indeed, in the characteristics of their production matrixes and markets. 


\section{Bibliography}

CEPalstat (Databases and Statistical Publications) (n/d) [online] http://estadisticas.cepal.org.

Dalgaard, E. and H. Sorensen (2002), "Consistency between PPP benchmarks and national price and volume indices", paper prepared for the 27th General Conference of the International Association for Research in Income and Wealth, Statistics Denmark [online] www.oecd.org/std/na/1957096.doc.

Deaton, A. and B. Aten (2014), "Trying to understand the PPPs in ICP 2011: why are the results so different?", NBER Working Paper, No. 20244, Cambridge, Massachusetts, National Bureau of Economic Research.

Dykstra, S., C. Kenny and J. Sandefur (2014), "Global absolute poverty fell by almost half on Tuesday", Center for Global Development [online] http://www.cgdev.org/blog/global-absolute-povertyfell-almost-half-tuesday.

ECLAC (Economic Commission for Latin America and the Caribbean) (2007), "Resultados del Programa de Comparación Internacional para América del Sur", Projects Document (LC/W.138), Santiago.

EU/IMF/OECD/United Nations/World Bank (European Commission/ International Monetary Fund/Organization for Economic Cooperation and Development/United Nations/World Bank) (2009), System of National Accounts 2008, New York.
Epstein, H. and S. Marconi (2014), "América Latina y el Caribe: estimación de las series en paridades de poder adquisitivo (PPA). Un ejercicio preliminar para el período 2000-2011”, Estudios Estadísticos series, No. 85 (LC/L.3781), Santiago, Economic Commission for Latin America and the Caribbean (ECLAC).

Heston, A. (various years), Penn World Tables (PWT) [online] https:// pwt.sas.upenn.edu/php_site/pwt_index.php.

IMF (International Monetary Fund), International Financial Statistics [online] http://elibrary-data.imf.org/QueryBuilder. aspx ?key=19784651\&s=322.

United Nations (n/d), United Nations Statistics Division [online] http://unstats.un.org/unsd/mdg/ Metadata.aspx? IndicatorId= 0\&SeriesId=699.

World Bank (2013), Measuring the Real Size of the Economy: The Framework, Methodology, and Results of the International Comparison Program (ICP), Washington, D.C.

(2008a), "Tables of results", 2005 International Comparison Program: Global Purchasing Power Parities and Real Expenditures, Washington, D.C.

(2008b), 2005 International Comparison Program (ICP): Global Purchasing Power Parities and Real Expenditures, Washington, D.C.

(n/d), "Datos de libre acceso del Banco Mundial" [online] http://datos.bancomundial.org/frontpage.

(n/d), "2011 global results" [online] http://icp.worldbank.org/. 
ANNEX A1

TABLE A1.1

Latin America and the Caribbean: purchasing power parities (PPP), ${ }^{\mathrm{a}} \mathbf{2 0 0 5 - 2 0 1 3}$

(National currency units per dollar)

\begin{tabular}{|c|c|c|c|c|c|c|c|c|c|}
\hline Country & 2005 & 2006 & 2007 & 2008 & 2009 & 2010 & 2011 & 2012 & 2013 \\
\hline Antigua and Barbuda & 1.71 & 1.67 & 1.68 & 1.72 & 1.74 & 1.74 & 1.73 & 1.74 & 1.71 \\
\hline Bahamas & 1.03 & 1.01 & 1.01 & 1.01 & 0.99 & 0.98 & 0.95 & 0.96 & 0.96 \\
\hline Barbados & 2.11 & 2.14 & 2.15 & 2.11 & 2.21 & 2.10 & 2.02 & 1.91 & 1.93 \\
\hline Belize & 1.12 & 1.14 & 1.16 & 1.17 & 1.13 & 1.13 & 1.15 & 1.15 & 1.15 \\
\hline Bolivia (Plurinational State of) & 2.02 & 2.23 & 2.33 & 2.52 & 2.44 & 2.62 & 2.95 & 3.10 & 3.23 \\
\hline Brazil & 1.09 & 1.13 & 1.16 & 1.23 & 1.31 & 1.40 & 1.47 & 1.52 & 1.61 \\
\hline Chile & 281.66 & 307.21 & 315.56 & 310.23 & 319.72 & 343.75 & 348.02 & 346.33 & 347.14 \\
\hline Colombia & 952.72 & 977.70 & 1000.36 & 1055.24 & 1082.98 & 1111.17 & 1161.91 & 1177.60 & 1177.98 \\
\hline Costa Rica & 233.30 & 251.24 & 267.69 & 295.09 & 317.41 & 338.54 & 346.74 & 354.55 & 366.83 \\
\hline Dominica & 1.82 & 1.81 & 1.79 & 1.79 & 1.91 & 1.84 & 1.86 & 1.88 & 1.87 \\
\hline Dominican Republic & 14.90 & 15.23 & 15.68 & 16.98 & 17.43 & 18.19 & 19.45 & 19.86 & 20.17 \\
\hline Ecuador & 0.39 & 0.41 & 0.43 & 0.48 & 0.48 & 0.51 & 0.53 & 0.54 & 0.55 \\
\hline El Salvador & 0.46 & 0.46 & 0.47 & 0.49 & 0.48 & 0.49 & 0.50 & 0.50 & 0.49 \\
\hline Grenada & 1.72 & 1.75 & 1.74 & 1.84 & 1.83 & 1.82 & 1.78 & 1.82 & 1.83 \\
\hline Guatemala & 2.84 & 2.89 & 3.02 & 3.24 & 3.33 & 3.46 & 3.63 & 3.68 & 3.75 \\
\hline Guyana & 83.85 & 85.93 & 94.34 & 100.87 & 102.24 & 107.78 & 114.43 & 118.87 & 117.33 \\
\hline Haiti & 13.04 & 14.52 & 15.28 & 16.92 & 17.41 & 18.14 & 19.11 & 19.76 & 20.76 \\
\hline Honduras & 7.57 & 7.74 & 8.04 & 8.50 & 9.08 & 9.39 & 9.91 & 10.09 & 10.09 \\
\hline Jamaica & 39.26 & 41.48 & 38.96 & 43.35 & 48.10 & 52.24 & 54.12 & 56.69 & 60.38 \\
\hline Mexico & 6.40 & 6.60 & 6.75 & 7.02 & 7.20 & 7.43 & 7.67 & 7.78 & 7.79 \\
\hline Nicaragua & 5.72 & 6.00 & 6.41 & 7.30 & 7.73 & 8.27 & 8.92 & 9.43 & 9.86 \\
\hline Panama & 0.49 & 0.49 & 0.49 & 0.52 & 0.52 & 0.54 & 0.55 & 0.56 & 0.57 \\
\hline Paraguay & 1708.76 & 1758.67 & 1880.39 & 2016.39 & 2042.07 & 2140.51 & 2227.34 & 2291.93 & 2268.09 \\
\hline Peru & 1.35 & 1.41 & 1.39 & 1.38 & 1.40 & 1.46 & 1.52 & 1.52 & 1.51 \\
\hline Saint Kitts and Nevis & 1.59 & 1.71 & 1.74 & 1.76 & 1.78 & 1.78 & 1.80 & 1.80 & 1.78 \\
\hline Saint Lucia & 1.69 & 1.73 & 1.81 & 1.76 & 1.74 & 1.84 & 1.84 & 1.86 & 1.89 \\
\hline Saint Vincent and the Grenadines & 1.65 & 1.65 & 1.74 & 1.70 & 1.68 & 1.73 & 1.69 & 1.68 & 1.67 \\
\hline Suriname & 1.21 & 1.24 & 1.28 & 1.45 & 1.54 & 1.63 & 1.83 & 1.99 & 2.02 \\
\hline Trinidad and Tobago & 3.40 & 3.32 & 3.66 & 4.44 & 3.19 & 3.40 & 3.94 & 3.78 & 3.86 \\
\hline Uruguay & 11.32 & 11.70 & 12.47 & 13.21 & 13.84 & 14.31 & 15.28 & 16.12 & 17.09 \\
\hline Venezuela (Bolivarian Republic of) & 0.85 & 0.98 & 1.10 & 1.40 & 1.50 & 2.16 & 2.71 & 3.04 & 4.21 \\
\hline
\end{tabular}

Source: Prepared by the authors, on the basis of Economic Commission for Latin America and the Caribbean (ECLAC), Databases and Statistical Publications (CEPALSTAT) [online] http://estadisticas.cepal.org/cepalstat/WEB_CEPALSTAT/Portada.asp?idioma=i; and World Bank Data Base [online] http://data.worldbank.org/.

a Extrapolated at the aggregate level. 
TABLE A1.2

Latin America and the Caribbean: total GDP in PPP, at current prices, ${ }^{\mathrm{a}}$ 2005-2013 (Millions of dollars)

\begin{tabular}{|c|c|c|c|c|c|c|c|c|c|}
\hline Country & 2005 & 2006 & 2007 & 2008 & 2009 & 2010 & 2011 & 2012 & 2013 \\
\hline Antigua and Barbuda & 1574 & 1840 & 2068 & 2110 & 1870 & 1758 & 1762 & 1866 & 1892 \\
\hline Bahamas & 7448 & 7870 & 8196 & 8163 & 7881 & 8100 & 8356 & 8593 & 8780 \\
\hline Barbados & 3694 & 4025 & 4201 & 4298 & 4152 & 4213 & 4333 & 4421 & 4500 \\
\hline Belize & 1986 & 2141 & 2222 & 2339 & 2373 & 2482 & 2587 & 2734 & 2817 \\
\hline Bolivia (Plurinational State of) & 38135 & 41192 & 44219 & 47858 & 49840 & 52531 & 56390 & 60373 & 65424 \\
\hline Chile & 247238 & 266530 & 286210 & 302511 & 301650 & 322929 & 348842 & 374216 & 395268 \\
\hline Colombia & 357038 & 392654 & 430919 & 454954 & 465981 & 490405 & 533513 & 565082 & 600331 \\
\hline Costa Rica & 40888 & 45844 & 50799 & 53210 & 53069 & 56379 & 60138 & 64361 & 67604 \\
\hline Dominica & 550 & 595 & 648 & 710 & 707 & 723 & 738 & 740 & 745 \\
\hline Dominican Republic & 73048 & 83327 & 92794 & 97588 & 99250 & 108802 & 114299 & 119445 & 126782 \\
\hline Ecuador & 105272 & 113284 & 118845 & 128879 & 130594 & 136849 & 150664 & 161376 & 171382 \\
\hline Grenada & 1090 & 1079 & 1175 & 1210 & 1138 & 1146 & 1179 & 1186 & 1233 \\
\hline Guatemala & 73103 & 79402 & 86654 & 91252 & 92429 & 96242 & 102318 & 107248 & 112852 \\
\hline Haiti & 12883 & 13578 & 14405 & 14812 & 15384 & 14716 & 15849 & 16599 & 17571 \\
\hline Honduras & 24273 & 26662 & 29065 & 30889 & 30367 & 31885 & 33791 & 35818 & 37307 \\
\hline Jamaica & 17831 & 18907 & 22727 & 23007 & 22153 & 22092 & 22931 & 23211 & 23689 \\
\hline Mexico & 1473580 & 1594433 & 1689647 & 1746559 & 1676347 & 1785035 & 1893303 & 2004931 & 2064130 \\
\hline Nicaragua & 18506 & 19867 & 21474 & 22520 & 22065 & 23072 & 24888 & 26590 & 28229 \\
\hline Panama & 33434 & 37400 & 43046 & 47904 & 50187 & 53772 & 60793 & 68226 & 75026 \\
\hline Paraguay & 31580 & 34115 & 36921 & 40039 & 38744 & 44351 & 47233 & 47485 & 55048 \\
\hline Peru & 185811 & 205939 & 229428 & 255316 & 259955 & 285366 & 310051 & 334398 & 358920 \\
\hline Saint Kitts and Nevis & 922 & 1006 & 1062 & 1127 & 1072 & 1050 & 1090 & 1096 & 1159 \\
\hline Saint Lucia & 1496 & 1669 & 1705 & 1799 & 1825 & 1828 & 1889 & 1892 & 1912 \\
\hline Trinidad and Tobago & 29579 & 34881 & 37410 & 39437 & 37992 & 38537 & 38317 & 39491 & 40737 \\
\hline Uruguay & 37549 & 40289 & 44067 & 48156 & 49662 & 54493 & 59702 & 63008 & 66758 \\
\hline Venezuela (Bolivarian Republic of) & 356492 & 403718 & 450741 & 483837 & 471902 & 470552 & 500326 & 537963 & 553312 \\
\hline Latin America and the Caribbean & 5181742 & 5622887 & 6091999 & 6459414 & 6407207 & 6847769 & 7266591 & 7625912 & 7955333 \\
\hline Latin America & 5109598 & 5542054 & 6003241 & 6367444 & 6318035 & 6757409 & 7174415 & 7531270 & 7858056 \\
\hline The Caribbean & 72144 & 80833 & 88758 & 91970 & 89172 & 90360 & 92176 & 94642 & 97277 \\
\hline
\end{tabular}

Source: Prepared by the authors, on the basis of Economic Commission for Latin America and the Caribbean (ECLAC), Databases and Statistical Publications (CEPALSTAT) [online] http://estadisticas.cepal.org/cepalstat/WEB_CEPALSTAT/Portada.asp?idioma=i; and World Bank Data Base [online] http://data.worldbank.org/.

Note: GDP: Gross domestic product; PPP: Purchasing power parities.

a Extrapolated at the aggregate level. 
TABLE A1.3

Latin America and the Caribbean: total GDP in PPP, at constant prices, ${ }^{\mathrm{a}}{ }^{2005-2013}$ (Millions of dollars at constant 2010 prices)

\begin{tabular}{|c|c|c|c|c|c|c|c|c|c|}
\hline Country & 2005 & 2006 & 2007 & 2008 & 2009 & 2010 & 2011 & 2012 & 2013 \\
\hline Antigua and Barbuda & 1732 & 1964 & 2151 & 2152 & 1893 & 1758 & 1726 & 1796 & 1794 \\
\hline Bahamas & 8195 & 8402 & 8523 & 8325 & 7978 & 8100 & 8187 & 8271 & 8326 \\
\hline Barbados & 4065 & 4297 & 4369 & 4384 & 4202 & 4213 & 4245 & 4255 & 4268 \\
\hline Belize & 2185 & 2285 & 2311 & 2385 & 2402 & 2482 & 2534 & 2631 & 2671 \\
\hline Bolivia (Plurinational State of) & 41963 & 43976 & 45983 & 48810 & 50449 & 52531 & 55249 & 58109 & 62046 \\
\hline Brazil & 2160497 & 2245989 & 2382801 & 2506030 & 2497767 & 2685941 & 2759343 & 2787792 & 2857289 \\
\hline Chile & 272054 & 284541 & 297630 & 308531 & 305333 & 322929 & 341785 & 360179 & 374855 \\
\hline Colombia & 392874 & 419187 & 448114 & 464008 & 471671 & 490405 & 522720 & 543885 & 569328 \\
\hline Costa Rica & 44992 & 48942 & 52826 & 54269 & 53717 & 56379 & 58922 & 61947 & 64113 \\
\hline Dominica & 605 & 635 & 674 & 724 & 716 & 723 & 723 & 713 & 706 \\
\hline Dominican Republic & 80380 & 88958 & 96497 & 99530 & 100462 & 108802 & 111987 & 114964 & 120235 \\
\hline Ecuador & 115838 & 120939 & 123587 & 131444 & 132189 & 136849 & 147616 & 155322 & 162532 \\
\hline El Salvador & 41092 & 42699 & 44339 & 44904 & 43497 & 44090 & 45068 & 45916 & 46685 \\
\hline Grenada & 1200 & 1152 & 1222 & 1234 & 1152 & 1146 & 1155 & 1142 & 1169 \\
\hline Guatemala & 80440 & 84768 & 90111 & 93068 & 93558 & 96242 & 100248 & 103225 & 107024 \\
\hline Haiti & 14176 & 14495 & 14980 & 15106 & 15572 & 14716 & 15529 & 15977 & 16663 \\
\hline Honduras & 26709 & 28463 & 30225 & 31504 & 30738 & 31885 & 33108 & 34475 & 35381 \\
\hline Jamaica & 19621 & 20184 & 23634 & 23465 & 22424 & 22092 & 22467 & 22340 & 22465 \\
\hline Mexico & 1621486 & 1702176 & 1757069 & 1781315 & 1696815 & 1785035 & 1855001 & 1929722 & 1957533 \\
\hline Nicaragua & 20364 & 21209 & 22331 & 22968 & 22334 & 23072 & 24385 & 25593 & 26771 \\
\hline Panama & 36790 & 39927 & 44763 & 48858 & 50799 & 53772 & 59564 & 65667 & 71152 \\
\hline Paraguay & 34749 & 36420 & 38394 & 40836 & 39217 & 44351 & 46277 & 45704 & 52205 \\
\hline Peru & 204461 & 219855 & 238583 & 260397 & 263129 & 285366 & 303778 & 321854 & 340384 \\
\hline Saint Kitts and Nevis & 1014 & 1074 & 1104 & 1150 & 1085 & 1050 & 1068 & 1055 & 1100 \\
\hline Saint Lucia & 1646 & 1781 & 1773 & 1835 & 1847 & 1828 & 1850 & 1821 & 1813 \\
\hline Saint Vincent and the Grenadines & 994 & 1070 & 1106 & 1124 & 1100 & 1063 & 1058 & 1070 & 1088 \\
\hline Suriname & 5580 & 6213 & 6531 & 6801 & 7006 & 7368 & 7756 & 7989 & 8219 \\
\hline Trinidad and Tobago & 32548 & 37238 & 38903 & 40222 & 38456 & 38537 & 37542 & 38009 & 38633 \\
\hline Uruguay & 41318 & 43012 & 45825 & 49114 & 50269 & 54493 & 58494 & 60644 & 63310 \\
\hline Venezuela (Bolivarian Republic of) & 392273 & 430999 & 468727 & 493466 & 477663 & 470552 & 490204 & 517783 & 524737 \\
\hline Latin America and the Caribbean & 5701842 & 6002851 & 6335085 & 6587958 & 6485440 & 6847769 & 7119586 & 7339848 & 7544497 \\
\hline Latin America & 5622457 & 5916555 & 6242786 & 6494157 & 6395179 & 6757409 & 7029275 & 7248756 & 7452243 \\
\hline The Caribbean & 79385 & 86296 & 92299 & 93801 & 90261 & 90360 & 90311 & 91092 & 92254 \\
\hline
\end{tabular}

Source: Prepared by the authors, on the basis of Economic Commission for Latin America and the Caribbean (ECLAC), Databases and Statistical Publications (CEPALSTAT) [online] http://estadisticas.cepal.org/cepalstat/WEB_CEPALSTAT/Portada.asp?idioma=i; and World Bank Data Base [online] http://data.worldbank.org/.

Note: GDP: Gross domestic product; PPP: Purchasing power parities.

a Extrapolated at the aggregate level. 